\title{
Impact of Public Policy Shocks on Components of Aggregate Demand in Pakistan
}

\author{
Saima Shafique1, Muhammad Mansoor Ali², Saif Mujahid Shah ${ }^{3}$ \\ ${ }^{1}$ Associate Professor, Department of Economics, NUML Islamabad \\ ${ }^{2}$ Assistant Professor, Department of Economics, NUML Islamabad \\ ${ }^{3}$ Lecturer, Department of Economics, NUML Islamabad
}

\section{A B S T R A C T}

Fiscal policy has strong distributional effects as alteration in tax rates and spending decisions cause different sectors of economy to respond differently. Correct information about this reaction and understanding transmission mechanism is essential to create policies that can have development and growth effects. The study analyzed impact of fiscal policy on disaggregated data of Pakistan in a SVAR setting. The analysis reveals an uneven distribution of fiscal policy shocks across different sectors of Pakistan with varying degree of responsiveness. There is heterogeneity in response of different sectors as well as components of aggregate demand in Pakistan to fiscal policy shocks as revealed in impulse response functions. It is results reveal that tax revenue shock generated higher response in different sectors than the government expenditure shock conforming to theoretical expectation that tax changes impact the agents faster than the expenditure decisions. This regressive behavior in Pakistan seems mostly due to higher spending on debt servicing and maintaining a large public sector with huge spending on pensions and social security networks.

Key Words: E62 Fiscal Policy; H3 Fiscal Policy and Behavior of Economic Agents; H5 National Government Expenditure and Related Policies.

\section{INTRODUCTION}

Public policy can have effects on economic activity of the economy through demand side instruments (Dweck et al., 2019). Government policies are used to remove fluctuations from business cycle to attain welfare of the society, but outcomes of fiscal initiatives can reconfigure aggregate demand and its components along with the expectations of the agents (Bongers \& Díaz-Roldán, 2019). These policy initiatives bring about changes that persist in short and long run by influencing returns of factors of production including human capital. Fiscal policy can affect research and development 
investments as well as rate of savings and investment along with labor force participation (Kim \& Nguyen, 2020: Curtis et al., 2020: Saiz-Alvarez \& Calleja-Leal, 2020). Therefore, fiscal policy impact assessment in terms of expenditures, taxes, and decisions about maintaining deficit is important to assess policy effectiveness and its response to different shocks in Pakistan mainly due to persistently dismal economic performance (Munir \& Riaz, 2019).

Advocating Keynesian perspective to use fiscal policy to stabilize economy has been subject to debate over the course of history (Munir \& Riaz, 2019). Keynesianism was severely criticized in the 1980s to present practical steps to handle oil price shock that caused huge deficit and debt in developing economies especially the US (Ahmed, 2018: Buggeln et al., 2017). But the global financial crisis of the late 2000s brought back the Keynesian perspective advocating active government role to stabilize economy as it seemed almost imperative for markets to return to equilibrium through government intervention to avert market failure (Stockhammer, 2016:Clift, 2019). Demand management policies through altering rates of taxation and/or public spending affected the course of economic recovery with short and long run impacts (Slemrod \& Bakija, 2017).

Generally disposable income and spending on one side and interest rates, investments and budget deficit on the other are affected by the changes in tax rates (Makin, 2018). The neo-classical theory advocates expansionary fiscal policy in terms of higher public spending or tax cuts but at the same time causes inflationary pressure on interest and crowds private investment (Anyanwu, et al., 2018: Nwachukwu et al, 2019:). Such fiscal initiatives can actually end up causing deflation if the loss in private sector output large and outweighs anticipated expansionary effect (Arellano et al., 2019). The expectation of increased tax and interest rates because of creating fiscal deficit causes fall in current consumption and higher supply of labor eventually reducing the real wages (Driessen \& Gravelle, 2019: Katagiri et al., 2019). But the proponents of new Keynesian school advocate the presence of sticky prices along with excess capacity and argue that higher public spending increases aggregate demand which is then reflected in matching supply thus generating positive vibes through multiplier effect especially in the short run 
(Chodorow-Reich, 2019). The higher fiscal deficits are a signal for higher future taxes but their justification comes in the logic of attainment of better future living standards and income generation capabilities of the society. But there is divided opinion about effectiveness of public spending in comparison with managing tax rates and transfers where the later is found to be more effective (Blinder, 1981). But countercyclical fiscal policy in times of low interest rates and time bound initiatives are more effective to generate stabilizing effects of fiscal policy as in Blanchard (2003) and (Charlton, 2019).

The average economic performance of Pakistan since 1980 has been consistent as it maintained 5\% growth rate of GDP on average but at the same time average inflation over the same time has been about $8 \%$ and current account balance of $-2.32 \%$ of the GDP on average. Every policy maker announces to achieve high growth rate with manageable inflation and fiscal deficit but so far it has proven to be a challenge for every subsequent government in Pakistan. The World Bank (WB) and the International Monetary Fund (IMF) have influenced governments in Pakistan to attain fiscal discipline by rationalizing tax rates, expenditures, size of public sector, and governance (Muhula, 2019). There are numerous factors that have caused the persistence of policies in Pakistan even though governments tried to initiate important infrastructure related investments with the help of donors. More dominant of such factors are: excessive borrowing from external and internal sources especially to finance war on terror, declining foreign direct investment, and inability to improve terms of trade (Asian Development Bank, 2002). Problems like these and other associated with them are the source of permanent and transitory shocks continuously affecting macro economy of Pakistan. Presence of these sources of shocks present a challenge for policy making institutions to create response and plans to offset the impact of such shocks. Economies respond differently to money and non-money means of fiscal deficit management but it is generally left to the policy maker to make the best possible mix to generate desirable outcomes in short as well as long run (Daniel, 2006). In Pakistan it is the money financed fiscal deficit management mainly due to very low tax propensity and narrow direct tax base (Ahmed, 2020). It has caused the economy of Pakistan to consume resources in managing twin deficit as continuous borrowing by the public sector has put upward pressure on interest rates thus suppressing private 
investments (Chaudhry, 2018). The expansion in tax base can actually supplement the overall economic performance by easing out the borrowing spree of the subsequent governments but the fear of losing political popularity has prevented the policy makers from making serious efforts even after the 18th constitutional amendment. The continuous increase in debt to GDP ratio and current account deficit are a massive opportunity cost for overall society to attain higher real growth and wage rates along with improvements in indicators of welfare and development.

\section{Objectives of the Study}

The study intends to determine the impact of shocks of government expenditures and taxes on components of aggregate demand in the economy i.e. private consumption, net exports, and private capital formation.

\section{LITERATURE REVIEW}

According to Dedola and Lippi (2005) and later Perotti (2007) stressed to understand the transmission mechanism of fiscal policy in order to achieve anticipated outcomes that can bring about changes in consumption, labour demand, exchange rates, corporate profits, interest rates, labour supply and private investment. But at the same time there are some factors that try to influence the policy interventions especially in the form of interest groups and political investors (Zaidi, 2010). In recent years government of Pakistan has tried to broaden tax base by including more items in sales tax regime and removing concessions on imported items like tea and edible oil resulting in increasing tax revenues (Economic Survey of Pakistan, 2019). Tax rate changes bring changes in consumption behavior of tax payers as Friedman's permanent income hypothesis holds that when house hold reduces consumption for maintaining permanent income whenever current income falls below average income (Friedman, 1977). In the US a small change in output elasticity of public expenditure induces a rise in private consumption and investments leading to enhanced exports and thrust in growth of the economy (Linnemann and Schabert, 2006). But Chen, Luan and Huang (2014) studies for China that public spending on education and culture causes increase in private consumption while spending on construction projects and public sector decreases it. Similarly, Davis 
and Henrekson (2005) found that corporate tax decisions affect formal as well as informal sectors by affecting planning about resources utilization and allocation. This also makes the private agents to revise expected profits and investment decisions for future project due to marginal tax rates (Hall and Jorgenson, 1967). The situation becomes further challenging for credit constrained firms as the risk of loss of future productivity increase due to increase in marginal and average tax rates (Devereux and Griffith, 2003).

\section{RESEARCH METHODOLOGY}

Study used SVAR to assess the impact of fiscal policy shocks and their understand transmission mechanism for different sectors of the economy. The order of variables entering the SVAR is: [tax revenue, government expenditure, aggregate output, and components of aggregate output]. SVAR can be given as:

$$
\left\{\begin{array}{c}
B X_{t}=\Gamma_{0}+\Gamma_{1} X_{t-1}+\cdots+\Gamma_{k} X_{t-k}+\varepsilon_{t} \\
B^{-1} B X_{t}=B^{-1} \Gamma_{0}+B^{-1} \Gamma_{1} X_{t-1}+\cdots+B^{-1} \Gamma_{k} X_{t-k}+B^{-1} \varepsilon_{t} \\
X_{t}=\mathrm{A}_{0}+\mathrm{A}_{1} X_{t-1}+\cdots+\mathrm{A}_{k} X_{t-k}+e_{t}
\end{array}\right.
$$

Where $X=\left[t_{t}, g_{t}, y_{t}, s_{i t}\right]^{\prime}$, and

$$
\left\{\begin{aligned}
A_{0} & =B^{-1} \Gamma_{0} \\
A_{1} X_{t-1} & =B^{-1} \Gamma_{1} X_{t-1} \\
e_{t} & =B^{-1} \varepsilon_{t}
\end{aligned}\right.
$$

The standard VAR can be written in VMA form as:

$$
\left[\begin{array}{l}
t_{t} \\
g_{t} \\
y_{t} \\
s_{i t}
\end{array}\right]=\left[\begin{array}{l}
\overline{t_{t}} \\
\overline{g_{t}} \\
\overline{y_{t}} \\
\overline{s_{u t}}
\end{array}\right]+\sum_{i=0}^{\infty} A_{1}^{i} e_{t-1}
$$

By replacing reduced form errors with structural errors (as $e_{t}=B^{-1} \varepsilon_{t}$ ) we get:

$$
\left[\begin{array}{l}
t_{t} \\
g_{t} \\
y_{t} \\
s_{i t}
\end{array}\right]=\left[\begin{array}{l}
\overline{t_{t}} \\
\overline{g_{t}} \\
\overline{y_{t}} \\
\overline{s_{u t}}
\end{array}\right]+\sum_{i=0}^{\infty} A_{1}^{i} B^{-1} \varepsilon_{t-1}
$$

Finally, impulse response functions can be traced as: 


$$
\left[\begin{array}{l}
t_{t} \\
g_{t} \\
y_{t} \\
s_{i t}
\end{array}\right]=\left[\begin{array}{l}
\overline{t_{t}} \\
\overline{g_{t}} \\
\overline{y_{t}} \\
\overline{s_{t t}}
\end{array}\right]+\sum_{i=0}^{\infty}\left[\begin{array}{llll}
\Phi_{11}^{(i)} & \Phi_{12}^{(i)} & \Phi_{13}^{(i)} & \Phi_{14}^{(i)} \\
\Phi_{21}^{(i)} & \Phi_{22}^{(i)} & \Phi_{23}^{(i)} & \Phi_{24}^{(i)} \\
\Phi_{31}^{(i)} & \Phi_{32}^{(i)} & \Phi_{33}^{(i)} & \Phi_{34}^{(i)} \\
\Phi_{41}^{(i)} & \Phi_{42}^{(i)} & \Phi_{43}^{(i)} & \Phi_{44}^{(i)}
\end{array}\right]^{(i-1}
$$

Similarly, the study assessed variance decomposition of each production sector of the economy as:

$$
\begin{aligned}
& \sigma_{s i, n}^{2}=\sigma_{t i}^{2}\left(\Phi_{11,0}^{2}+\Phi_{11,1}^{2}+\cdots+\Phi_{11_{l} k-1}^{2}\right)+\sigma_{g i}^{2}\left(\Phi_{21,0}^{2}+\Phi_{21,1}^{2}+\cdots+\Phi_{21, k-1}^{2}\right)+ \\
& \sigma_{y i}^{2}\left(\Phi_{31_{1} 0}^{2}+\Phi_{31_{i} 1}^{2}+\cdots+\Phi_{31_{l} k-1}^{2}\right)+\sigma_{s i}^{2}\left(\Phi_{41_{i} 0}^{2}+\Phi_{41_{i} 1}^{2}+\cdots+\Phi_{41_{l} k-1}^{2}\right)
\end{aligned}
$$

The output of a specific sector is presumed to be exogenous to changes in the system if $\varepsilon_{t}$ and $\varepsilon_{y}$ do not explain error forecast variance that is:

$$
\left(\partial \sigma_{s i, n}^{2} / \partial \sigma_{t}^{2} \approx 0\right),\left(\partial \sigma_{s i, n}^{2} / \partial \sigma_{g t}^{2} \approx 0\right)\left(\partial \sigma_{s i, n}^{2} / \partial \sigma_{y t}^{2} \approx 0\right) .
$$

Blanchard and Perotti (2002) used event study approach to identify the system and get the structural and reduced form shocks. Although annually there is only one incidence of budget presentation but in practice fiscal authorities continue to make revised plans due to unforeseen events. The identification of the system was achieved as:

$$
\left\{\begin{array}{l}
e_{t t}=a_{1} e_{y t}+a_{2} \varepsilon_{g t}+\varepsilon_{t t} \\
e_{g t}=b_{1} e_{y t}+b_{2} \varepsilon_{t t}+\varepsilon_{g t} \\
e_{y t}=c_{1} e_{t t}+c_{2} e_{g t}+\varepsilon_{y t} \\
e_{s t}=d_{1} e_{t t}+d_{2} e_{g t}+\varepsilon_{s t}
\end{array}\right.
$$

Where ${ }^{e_{s t}}$ and $\varepsilon_{g t}$ represent reduced form and structural errors respectively for a specific sector. The reduced form shocks ${ }^{e_{t t}}$ and ${ }^{e_{g t}}$ are generated due to onetime rise in taxes or expenditures by a standard deviation happening once a year. There can be two explanations for setting off the fiscal shocks: first, imperfect foresight and decisions made accordingly by the agents, and; second, alterations in various spending by fiscal authorities enjoying discretion in this regard. The study identified model by considering 
first cause whereas second cause is the consequence of influence exerted by different interest groups to channelize public spending in their favor (Zaidi, 2010). The shocks so generated were used in order to generate impulse response functions for different sectors of the economy. The cyclically adjusted reduced form shocks for policy variables i.e. tax and government expenditures are formulated as:

$$
\begin{gathered}
(1.8) \quad e_{t t}^{c a}=e_{t t}-a_{1} y_{t} \\
e_{g t}^{c a}=e_{g t}-b_{1} g_{t}=e_{g t}\left(\text { since } b_{1}=0\right)
\end{gathered}
$$

The coefficients $a_{1}$ and $b_{1}$ describe impact of aggregate output on tax revenue and governing expenditure under the current rules and adjustment made due to discretion enjoyed by the policy maker in order to make up for impact of any unforeseen event. The coefficients $d_{1}$ and ${ }^{d_{2}}$ represent impact of tax and expenditure shocks on components of aggregate output. All the variables entered the system in stationary form and study used GMM to estimate all the coefficients.

\section{RESULTS AND ANALYSIS}

The study traced the effect fiscal policy shocks on components of aggregate demand i.e. private consumption, capital formation and net exports.

\subsection{Private Consumption}

Tax shocks affect not only the demand side but also the supply side when changes occur in prices of commodities, wage rates, consumption expenditure and overall resources allocation (Geerolf \& Grjebine, 2018). It is generally believed that a positive tax shock will cause fall in household consumption expenditure but its responsiveness largely depends on type of taxes imposed and the way individual plan their consumption (Steindel, 2001). At the same time the analysis must also consider the impact of tax structure and reforms introduced by the policy makers. Taxes on certain durables do not immediately modify the consumption pattern of the household, and same is true for products used in manufacturing activities and commercial communication technologies for commuting and information technology. 
Panel (a)

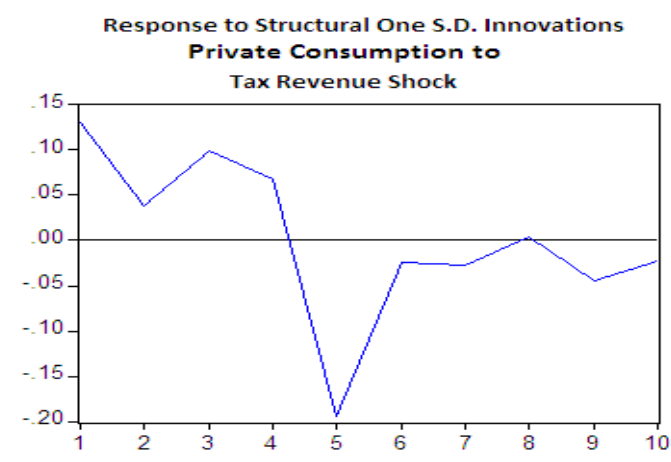

Panel (c)

Response to Structural One S.D. Innovations Private Consumption to Aggregate Output Shock

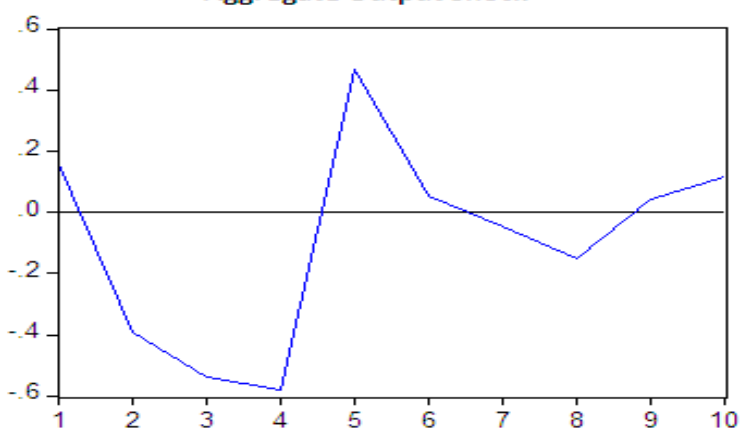

Panel (b)
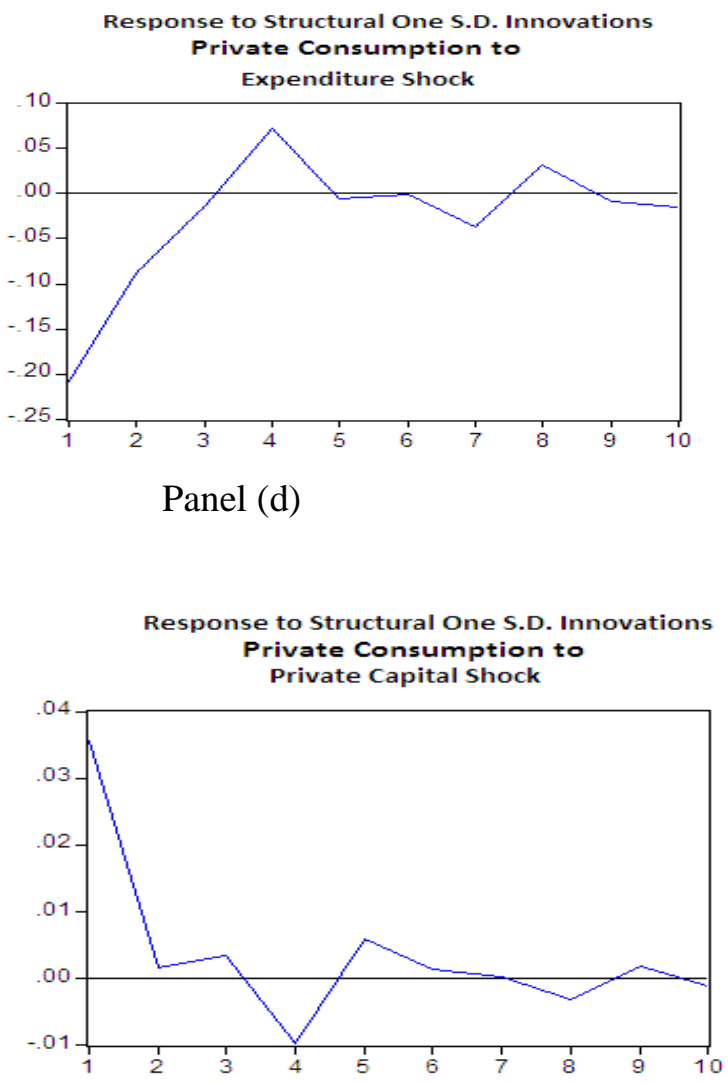

Figure 1. Response of Private Consumption to Structural Shocks

Government of Pakistan has struggled to increase the tax base as out of 200 million less than 10 million are direct payers forcing the policy makers to rely heavily on indirect taxes to make up for revenue shortfall. In recent years government of Pakistan has tried to broaden tax base by including more items in sales tax regime and removing concessions on imported items like tea and edible oil resulting in increasing tax revenues in 2015-16 (Economic Survey of Pakistan, 2016). Government of Pakistan changed and revised tax slabs causing bracket creep causing a surge from tax payers to exploit the shortcomings of tax structure. Rate of general sales tax was $15.78 \%$ in 2006 and 
increased steadily to $17 \%$ in 2014 and remained same to date. Government of Pakistan has increased the tax revenue and expenditure over past few years amassing a large amount of internal and external debt. The use of such measures keeps the voters unaware of such revenue and expenditure regimes causing fiscal illusion and low level of accountability of policy makers. This hidden tax burden is the reason for a continuous decline of household expenditures and real wages in general. This behavior is in line with Friedman's permanent income hypothesis when house hold reduces consumption for maintaining permanent income whenever current income falls below average income (Friedman, 1977).

Response of private consumption to tax revenue shock remains positive for four years after which starts to decline in the long run. But on the other hand private consumption is suppressed due to government expenditure shock that converges to equilibrium in third year after which remains stable. Response of private consumption to aggregate output shock is positive upon impact but continues to decline for four years, after which starts to recover to equilibrium. But on the other hand own shock produces a positive response that lasts for three years after which remains stable. The analysis of variance decomposition reveals that most part of variability of private consumption is explained by tax and government expenditure shocks, but the impact of aggregate output shock only starts to become stronger over the long run.

Linnemann and Schabert (2006) showed that for the US economy a small change in output elasticity of public expenditure induces a rise in private consumption and investments leading to enhanced exports and thrust in growth of the economy. But for China it is public spending on education and culture that causes increase in private consumption while spending on construction projects and public sector decreases it (Chen, Luan and Huang, 2014). The finding of the study comply with these earlier findings and it can inferred that in Pakistan the huge expenses on maintaining public sector and infrastructural investments are causing pressure on private consumption expenditure.

Pakistan has high marginal propensity to consume like other developing countries and it has consumption-led growth pattern. This is evident in high private and 
public consumption expenditures of about $78.98 \%$ and $10.68 \%$ of GDP in 2017 (Economic Survey of Pakistan, 2017). Frail response of private consumption to government expenditure shocks in Pakistan is mainly due to high debt-GDP ratio that crowds out productive investment and making household credit constrained. This is aggravated because of low productivity, trade deficit and regressive rate of economic growth. Ricardian equivalence asserts that the impact of public expenditure is same whether it is funded through taxes or borrowing. But in the New-Keynesian framework the positive response in private consumption due to public spending shock can only happen if monetary policy is accommodative to fiscal policy initiatives (Linnemann \& Schabert, 2006). Therefore, it can be inferred from the results of the study that in Pakistan the policy coordination is necessary to have desired outcomes of public policy for managing recessions and decreased economic activity in general.

\subsection{Private Investment \& Capital Formation}

The impact of fiscal policy alterations manifest in multiple ways that have strong bearing on decisions of firms regarding productivity and expansion of future of investments. The corporate tax decisions affect formal as well as informal sectors especially when it comes to planning resources utilization and allocation (Davis \& Henrekson, 2005). This also makes the private agents to revise expected profits and investment decisions for future project due to marginal tax rates (Hall \& Jorgenson, 1967). The situation becomes further challenging for credit constrained firms as the risk of loss of future productivity increase due to increase in marginal and average tax rates (Devereux \& Griffith, 2003).

The study traces a positive response of private investment and capital formation due to tax revenue, government expenditure, aggregate output own shocks upon impact that remains volatile over the entire forecast horizon. The response of private investment and capital formation to these shocks is although volatile but remains positive for most part of forecast horizon. The analysis of variance decomposition shows that tax revenue and government expenditure shocks explain most of the variability in private investment and capital formation, but the impact of aggregate output shock starts to get stronger only in the long run. The study further found that reverse causality exists between private 
investment and capital formation and aggregate output. But Granger causality test reveals unidirectional causality from tax revenue, government expenditures and aggregate output to private investment and capital formation. The results of Co-integration analysis reveal a stable long run relationship of private investment and capital formation with other variables in the system, confirming to general economic wisdom.

Panel (a)

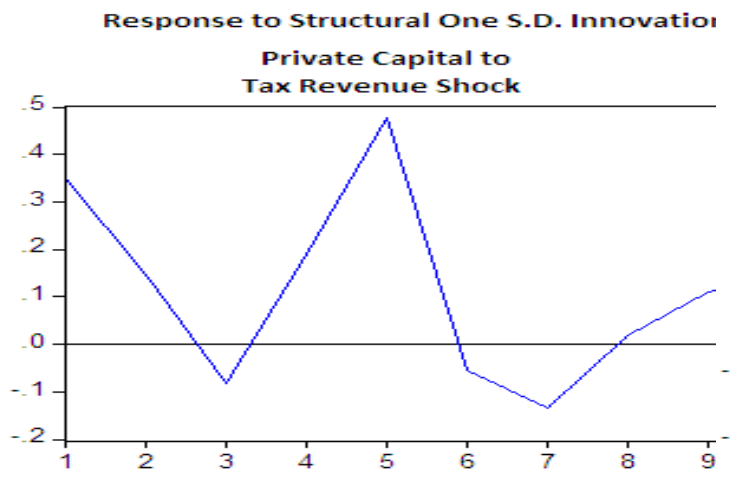

Panel (c)

Response to Structural One S.D. Innovatio

Private Capital to

Aggregate Output Shock

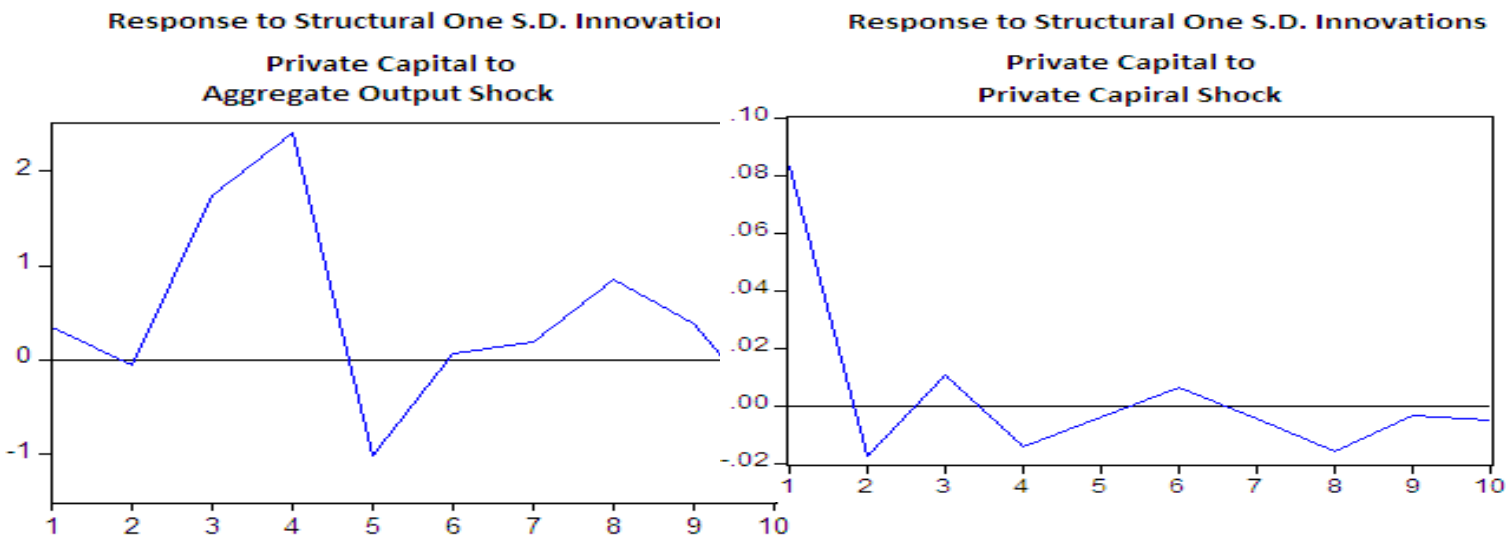

Panel (b)

Response to Structural One S.D. Innovations

Private Capital to

Expenditure Shock

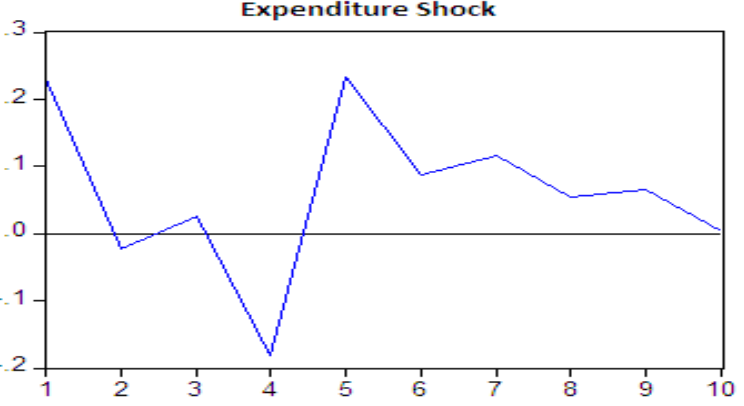

Panel (d)

Figure 2. Response of Private Capital Formation to Structural Shocks

Although policy makers and businesses use information of effective tax rate to assess tax burden to forecast investment returns but added information of related taxes (e.g. property taxes, licensing taxes, wealth and capital gains taxes, asset and capital taxes, the value-added tax, the sales tax etc.) business and consumption is also needed 
for correct business forecasting (King and Fullerton, 1984). Policy makers are trying to maintain a tax regime that does not have regressive effect on corporate growth by maintaining a flat $35 \%$ tax on corporate income and comparatively lower taxes on dividends and capital gains (Paying Taxes 2014: The Global Perspective, 2014).

\subsection{Net Exports}

The literature about assessing impact of domestic tax policies and international trade performance of Pakistan is very scarce. This is especially important in the regime of trade liberalization and formation of new trade blocks and routes. The back lash of trade liberalization is that if the domestic tax structure is not conducive for corporate growth, it has become very easy to move the regions with more producer friendly tax regimes. Pakistan is already bearing the impacts of war on terrorism and does not present a viable place for foreign direct investment. Even the investments of the overseas nationals are not very encouraging in number and amount. This aggravates the external account balance as the deficit has reached as high as \$ 2.12 billion (Economic Survey of Pakistan, 2017). This situation forces government to borrow from either supra national institutions or governments to maintain a reasonable foreign exchange reserves for meeting domestic needs.

Tax revenue, government expenditure, aggregate output and own shocks generate a stable response in net exports that is volatile around equilibrium and starts to become unstable only over the long run. The analysis of variance decomposition shows that all the variables in the system explain the variability in net exports consistently.

The behavior of net exports to the fiscal policy measures show a consistent response indicating a well-organized exports sector that responds well to fiscal policy shocks. In Pakistan, subsequent governments have tried to create policies that are conducive to boost the exports-led growth. This is specifically true for boosting the performance of textile sector by meeting their requirements of power and gas on priority. The dismal performance of energy sector during the regime of Pakistan People Party caused a chaos in textile sector that was seen in fall in exports earnings and labor force panic. Government at that time tried to redress and address the needs of textile exporters, and since then subsequent governments have taken measures to keep the exporting sector 
of the economy stress free.

Panel (a)

Response to Structural One S.D. Innovati

Net Exports to

Revenue Shock

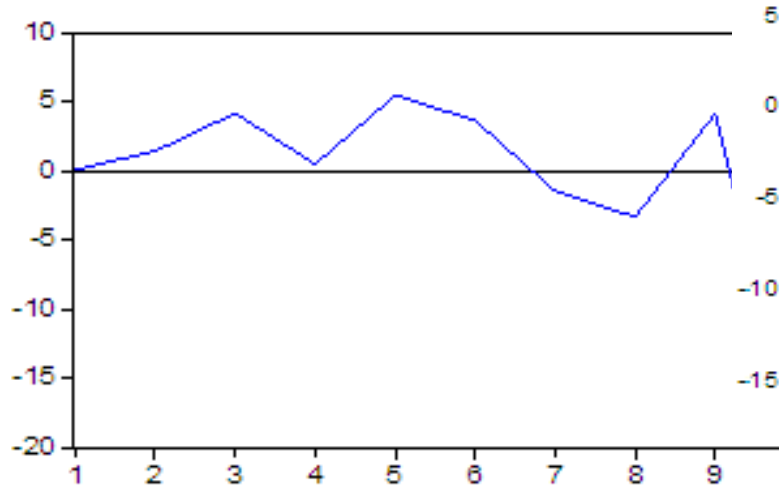

Panel (c)

Response to Structural One S.D. Innova

Net Exports to
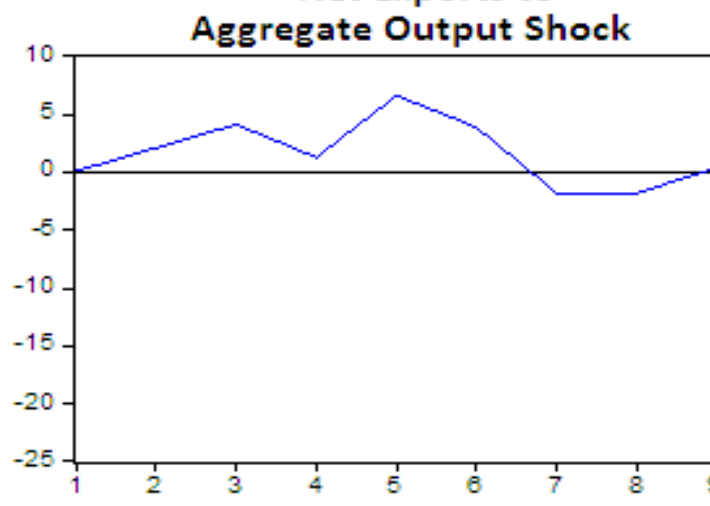

Figure 3. Response of Net Exports to structural

Shocks

\section{CONCLUSION}

It is revealed in the study that in Pakistan the effects of fiscal policy shocks are not evenly distributed among different components of aggregate demand. The responses of different components to fiscal shocks reveal that each sector behaves differently to

\section{Net Exports to}

Expenditure Shock

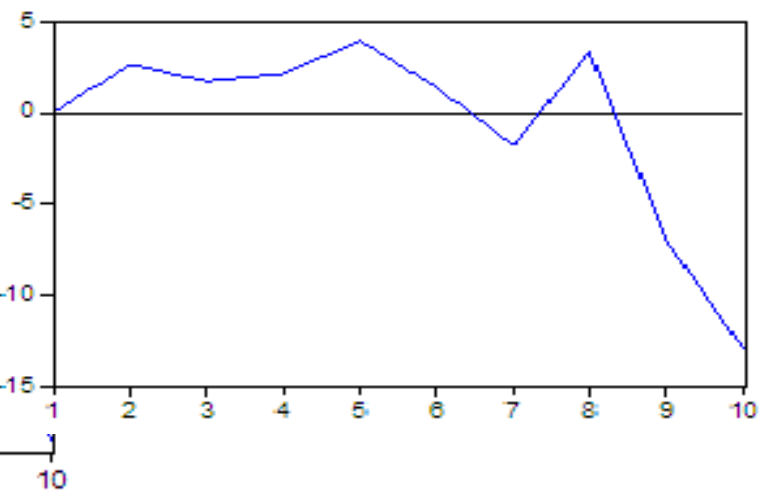

Panel (d)

Response to Structural One S.D. Innovations

Net Exports to

Net Exports Shock

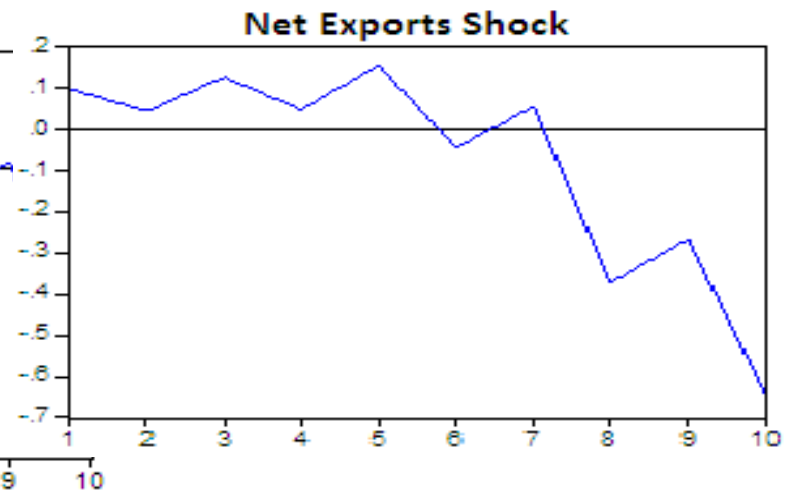


these shocks calling for insight from the policy makers to craft and implement policy initiatives. The peak values of impact multipliers due to tax revenue shocks were attained comparatively earlier than those due to government expenditure shocks. Therefore, tax changes have faster impact than the expenditure shocks in Pakistan. Agents reformulate their expectations faster due to tax revenue shocks than the government expenditure shocks. One of the unexpected finding of the study is that tax revenues shock generates a positive output response in different sectors whereas it is regressive for government expenditure shock. This calls for a deeper insight into the composition of government spending as each type of spending has its own impact on performance of the economy. it is seen that most part of government spending is consumed on either debt servicing, maintaining a huge public sector, pensions payments and maintenance of existing infrastructure. Therefore, public spending does not have profound planned impact on aggregate economy that falls heavily on tax policy and structure to be used in a manner that can enhance growth performance of Pakistan.

\section{REFERENCES}

Adolfson, Malin \& Laséen, Stefan \& Lindé, Jesper \& Villani, Mattias. (2005) Bayesian Estimation of an Open Economy DSGE Model with Incomplete Pass-Through. Working Paper Series 179, Sveriges Riksbank

Ahmed, M. A. (2020). Pakistan's BOP Blues: Demons in the Debit Side-An Elitist Analysis of the Outward Remittance Regime-Bringing the Tax Pincer Back In. Journal of Taxation and Regulatory Framework, 3(1), 1-34.

Ahmed, S. (2018). Money, the Real Economy and Financial Services. In Ruling or Serving Society? (pp. 15-42). Palgrave Macmillan, Cham.

Alesina, Alberto, Perotti, Roberto (1995). Fiscal Expansions and Adjustments in OECD Countries. Discussion Paper Series No. 754, Economic Policy Panel, 154-167.

Anyanwu, A., Gan, C., \& Hu, B. (2018). Government domestic debt, private sector credit, and crowding out effect in oil-dependent countries. Private Sector Credit, and Crowding Out Effect in Oil-Dependent Countries (July 15, 2018).

Arellano, C., Bai, Y., \& Kehoe, P. J. (2019). Financial frictions and fluctuations in volatility. Journal of Political Economy, 127(5), 2049-2103.

Asian Development Bank, (2002). Poverty In Pakistan Issues, Causes And Institutional Responses. Retrieved from https://www.adb.org/sites/default/files/institutionaldocument/ 33464 /files/poverty.pdf

Barro, Robert J. (1979). On the Determination of the Public Debt. Journal of Political Economy 87 (5): 940-971

Bartolini, D. and Santolini, R. (2009). Fiscal Rules and the Opportunistic Behavior of the Incumbent Politician: Evidence from Italian Municipalities. CESifo WP, N. 2605.

Bongers, A., \& Díaz-Roldán, C. (2019). Stabilization policies and technological shocks: 
towards a sustainable economic growth path. Sustainability, 11(1), 205-222.

Buggeln, M., Daunton, M., \& Nützenadel, A. (2017). The Political Economy of Public Finance: Taxation, State Spending and Debt Since the 1970s. Cambridge University Press.

Chang, Jing Hun., Chen, Been-Lon. and Hsu, Mei. (2006) Agriculture Productivity and Economics Growth: Role of Tax Revenues and Infrastructures. Southern Economic Journal, (72)6: 891-914.

Charlton, A. (2019). Fiscal policy in extraordinary times: A perspective from Australia's experience in the global recession. Economic Analysis and Policy, 64, 83-90.

Chaudhry, M. E. (2018). Interest Payments, Fiscal Deficit and Economic Growth: A Case Study of Pakistan. Kashmir Economic Review, 27(1).

Chodorow-Reich, G. (2019). Geographic cross-sectional fiscal spending multipliers: What have we learned?. American Economic Journal: Economic Policy, 11(2), 1-34.

Clift, B. (2019). Contingent Keynesianism: the IMF's model answer to the post-crash fiscal policy efficacy question in advanced economies. Review of International Political Economy, 26(6), 1211-1237.

Curtis, A., McVay, S., \& Toynbee, S. (2020). The changing implications of research and development expenditures for future profitability. Review of Accounting Studies,2(3) 1-33.

Daniel, J. (2006). Fiscal adjustment for stability and growth (No. 55). International Monetary Fund.

Doran, Michael (2008) Intergenerational Equity in Fiscal Policy Reform. Tax Law Review; 61, 3, 128-142.

Driessen, G. A., \& Gravelle, J. G. (2019). Deficit Financing, the Debt, and" modern Monetary Theory". Congressional Research Service. Retrieved from https://www.everycrsreport .com/ files/201910 21 _ R45976_141db8331748 56ddd57fcdec89bf68928a7a7 8de.pdf

Dweck, E., Vianna, M. T., \& da Cruz Barbosa, A. (2019). Discussing the role of fiscal policy in a demand-led agent-based growth model. EconomiA (154)2, 1-24

Economic Survey of Pakistan (2016). Pakistan economic survey 2015-16, Government of Pakistan: Ministry of finance. Retrieved from http://www.finance.gov.pk/ survey 1517. html

Economic Survey of Pakistan (2017). Pakistan economic survey 2016-17, Government of Pakistan: Ministry of finance. Retrieved from http://www.finance.gov.pk/survey_1517 .html

Economic Survey of Pakistan (2019). Pakistan economic survey 2018-19, Government of Pakistan: Ministry of finance. Retrieved from http://www.finance.gov.pk/survey_1517.html

Gale, W. G., Orszag, P. R. (2003). Economic Effects of Sustained Budget Deficits. National Tax Journal, 56, 463-485.

Geerolf, F., \& Grjebine, T. (2018). The Macroeconomic Effects of Lump-Sum Taxes. Working Paper.

Retrieved

from

https://pdfs.semanticscholar.org/8a37/e1ddde6c1f67

f60aedfd8126c61.pdf?_ga=2.235004353.1785666721.1588892940-

1987314970.1584989689

Islamabad Chamber of Commerce and Industry (2011). An Overview of Electricity Sector in Pakistan.

Jordan, A., Craigwell, R. \& Carter, A. (2000). The Potency of Monetary and Fiscal Policies in Caribbean Countries: A Cointegrating VAR approach. Savings \& 
Development, 24(3), 325-342.

Katagiri, M., Konishi, H., \& Ueda, K. (2019). Aging and deflation from a fiscal perspective. Journal of Monetary Economics.2(3), 1-15.

Keynes, John Maynard. (1936). The General Theory of Employment, Interest and Money. Palgrave-McMillan, London (UK).

Kim, T., \& Nguyen, Q. H. (2020). The effect of public spending on private investment. Review of Finance, 24(2), 415-451.

Lucas, Robert (1976). Econometric Policy Evaluation: A Critique. In Brunner, K.; Meltzer, A. The Phillips Curve and Labor Markets. Carnegie-Rochester Conference Series on Public Policy 1. New York: American Elsevier: 19-46.

Makin, A. J. (2018). Budget Deficits, Public Debt and Crowding Out. In The Limits of Fiscal Policy (pp. 31-44). Palgrave Pivot, Cham.

Malik, M. H. and Saqib, N. (1989). Tax incidence of income class in Pakistan. Pakistan Development Review, Vol. 28, No. 1 (spring), pp. 13-26.

Markwell, Donald (2006). John Maynard Keynes and International Relations: Economic Paths to War and Peace, Oxford University Press.

Marsden K., (1983). Links between taxes and economic growth. World Bank Staff Working Paper Number 605, The World Bank, Washington, D.C.

Muhula, R. (2019). Pakistan at 100: Governance and Institutions. World Bank. Retrived from https://doi.org/10.1596/31412.

Munir, K., \& Riaz, N. (2019). Fiscal Policy and Macroecomonic Stability in South Asian Countries. Hacienda Publica Espanola/Review of Public Economics. 228(1/2019): 13-33

Munir, K., \& Riaz, N. (2019). Macroeconomic effects of fiscal policy in Pakistan: a disaggregate analysis. Applied Economics, 51(52), 5652-5662.

Nwachukwu, A. C., Chikezie, A. O., \& Uzoma, K. P. (2019). The Impact of Budget Deficit On Nigeria Economic Growth (1980-2017). International Journal of Arts, Languages And Business Studies, 2(2), 345-365.

Pakistan Minerals Working Group. (2013). Bringing Mining in Pakistan up to International Standards.

Phillips, P. C. B.; Perron, P. (1988). Testing for a Unit Root in Time Series Regression. Biometrika 75 (2): 335-346.

Prescott, Edward C., Richard T. and Ely Lecture. (2002). Prosperity and Depression. American Economic Review, Papers and Proceedings, 92, no. 2: 1-15.

Romer, C.D., and D.H. Romer (2007). The Macroeconomic Effects of Tax Changes: Estimates Based on a New Measure of Fiscal Shocks. NBER Working Paper 13264. Cambridge, $M A$.

Saiz-Alvarez, J. M., \& Calleja-Leal, G. (2020). Fiscal Policy and Social Optimization for Developing Nations: Some Thoughts in the Digital Era. In Handbook of Research on Social and Organizational Dynamics in the Digital Era (pp. 292-304). IGI Global.

Saqib Saima., Ali, Tariq. Riaz, Muhammad Faraz. Anwar, Sofia. and Aslam, Amir. (2014). Taxation Effects on Economic Activity in Pakistan. Journal of Finance and Economics, 2014, Vol. 2, No. 6: 215-219.

Slemrod, J., \& Bakija, J. (2017). Taxing ourselves: a citizen's guide to the debate over taxes. MIT press.

State Bank of Pakistan, Infrastructure and Housing Finance Division. (2009). Development of Strategic Goals for Housing Development in Pakistan: $p-3$.

Steindel, C. (2001). The effect of tax changes on consumer spending. Current issues in 
economics and finance, 7(11).

Stockhammer, E. (2016). Neoliberal growth models, monetary union and the Euro crisis. A post-Keynesian perspective. New political economy, 21(4), 365-379.

Tanzi, Vito (1996). Fiscal Federalism and Decentralization: A Review of Efficiency and Macroeconomic Aspects. Annual World Bank Conference on Development Economics.

Taylor, W., and Taylor, L. (1993). Postdivestiture Long Distance Competition in the United States. AER Papers and Proceeding, pp: 185-190

The World Bank / IFC \& Price Waters Coopers (2014). Paying Taxes 2014: The Global Picture. The UK: Author.

Zaidi, Akbar S (2010). Pakistan's Roller-Coaster Economy: Tax Evasion Stifles Growth. Policy Brief, Carnegie Endowment for International Peace. Washington.

Zubairy, S. (2010). On fiscal multipliers: Estimates from a medium scale DSGE model. Bank of Canada Working Paper 2010-30. 